\title{
THE EFFECTS OF RESISTANCE EXERCISES ON THE NITROGEN, PHOSPHORUS, AND CALCIUM METABOLISM OF PATIENTS WITH RHEUMATOID ARTHRITIS 1,2
}

\author{
By WILLIAM S. CLARK, 3 ARTHUR L. WATKINS, HENRICK O. TONNING,4 AND \\ WALTER BAUER
}
(From the Departments of Medicine and Physical Medicine, Massachusetts General Hospital, the Department of Medicine, Harvard Medical School, and the Massachusetts Department of Public Health)

(Submitted for publication October 30, 1953; accepted December 9, 1953)

Muscle weakness and atrophy are common and disabling manifestations of rheumatoid arthritis for which various types of active exercises are usually prescribed. It is well known that active exercises result in substantial increases in muscle mass and power only when performed repeatedly against resistance with considerable physical effort (1). Although physical activity has been reported to have a protein-anabolic effect and cause calcium retention in normal subjects $(2,3)$, the metabolic responses to exhaustive physical exertion during active rheumatoid arthritis have not been investigated. These studies were undertaken to determine the effects of heavy resistance exercises on nitrogen, phosphorus, and calcium metabolism in patients experiencing exacerbations of this disease.

\section{SUBJECTS}

1. M. M., a 42-year-old male, noted symptoms of arthritis ten years before admission, characterized by pain in the right hip for six months. Eight, six, and four years before admission, he experienced attacks involving the right shoulder, the left shoulder, and feet, respectively. Four months prior to hospitalization, he developed severe, stiffness and pain in the hands, wrists, elbows, shoulders, hips, knees, and ankles. The fingers, wrists, elbows, and knees became swollen, and nodules appeared over the olecranons. He had had anorexia, marked weakness and fatigue, and had lost 30 pounds.

His height was $185 \mathrm{~cm}$., weight, $69.0 \mathrm{Kg}$.; blood pressure, $130 / 80$; and temperature, $98.6^{\circ} \mathrm{F}$. The liver edge was palpable $5 \mathrm{~cm}$. below the right costal margin. Cervical, axillary, epitrochlear, and inguinal lymph nodes were

1 This is publication number 157 of the Robert W. Lovett Memorial for the study of crippling disease.

2 The expenses of this investigation were defrayed in part by a grant from the Commonwealth Fund.

${ }^{8}$ Present address: The Benjamin Rose Hospital, 2073 Abington Road, Cleveland 6, Ohio.

4 Present Address: 44 Coburg Street, St. John, N.B., Canada. present. Muscle atrophy was apparent in the upper extremities. There was soft tissue swelling of the phalangeal joints, wrists, elbows, knees, ankles, and feet and effusions were present in both knees. Joint motion was moderately limited in the wrists, elbows, shoulders, hips, and cervical spine.

Laboratory studies revealed a normal urine, a corrected sedimentation rate of $1.38 \mathrm{~mm}$. per minute, and a hemoglobin of 12.5 grams per cent. Urinary $17-$ ketosteroids were $10.8 \mathrm{mg}$. in twenty-four hours.

$\mathrm{X}$-ray studies revealed minimal osteoporosis of the carpal bones and slight spur formation at the margins of the coronoid processes and olecranons. There was marked osteoporosis of the tarsals and metatarsals.

2. J. W., a 47-year-old white male, developed rheumatoid arthritis three years before admission with swelling, aching, redness, and heat in the second and third metacarpophalangeal and mid-phalangeal joints of both hands, subsiding in three weeks. Nine months before admission, he developed pain and swelling in the left wrist. This pain subsided within three months but slight swelling remained. Two months before admission he developed pain and swelling in both ankles, the right large toe, right elbow, and left knee. During the two months before admission, he experienced marked fatigue and anorexia and lost twenty-seven pounds.

His height was $178.7 \mathrm{~cm}$., weight, $80 \mathrm{Kg}$., blood pressure, $125 / 70$, and temperature $98.6^{\circ} \mathrm{F}$. There was soft tissue swelling of the midphalangeal joints, wrists, left knee, and both ankles. A small effusion was present in the left knee. Motion was limited in the right hand, both wrists, right elbow, and both ankles.

Laboratory studies revealed a normal urine, a corrected erythrocyte sedimentation rate of $1.55 \mathrm{~mm}$. per minute, and a hemoglobin of 12.5 grams.

$\mathrm{X}$-ray studies revealed considerable osteoporosis of the ends of the long bones of both hands and narrowing of the joint spaces of the right fourth metacarpophalangeal joint and several interphalangeal joints.

\section{PROCEDURE}

Three balance studies were performed in accordance with methods described by Reifenstein, Albright, and Wells (4). Stools were collected in six-day periods and urines in three and six-day periods. Diets, urines, and stools 
W. S. CLARK, A. L. WATKINS, H. O. TONNING, AND W. BAUER

TABLE I

M. M.-Nitrogen, phosphorus, and calcium balance data (in grams per period)

\begin{tabular}{|c|c|c|c|c|c|c|c|c|c|}
\hline Period & $\underset{\text { urine }}{\text { CA }}$ & $\begin{array}{c}\text { CA } \\
\text { stool }\end{array}$ & $\begin{array}{c}\text { CA } \\
\text { balance }\end{array}$ & $\begin{array}{c}P \\
\text { urine }\end{array}$ & $\underset{\text { stool }}{\mathrm{P}}$ & $\begin{array}{c}\mathbf{P} \\
\text { balance }\end{array}$ & $\underset{\text { urine }}{\mathrm{N}}$ & $\begin{array}{c}\mathrm{N} \\
\text { stool }\end{array}$ & $\begin{array}{c}\mathrm{N} \\
\text { balance }\end{array}$ \\
\hline $\begin{array}{c}1 \\
2 \\
3 \\
4 \\
5^{*} \\
6^{*} \\
7^{*} \\
8^{*} \\
9^{*} \\
10^{*} \\
11 \\
12 \\
13 \\
14 \\
1 \\
2 \\
3 \dagger \\
4 \dagger \\
5 \dagger \\
6 \dagger \\
7 \\
8 \\
9\end{array}$ & $\begin{array}{l}1.092 \\
1.055 \\
1.091 \\
1.115 \\
1.130 \\
1.013 \\
0.962 \\
1.061 \\
0.958 \\
0.977 \\
0.901 \\
0.926 \\
0.988 \\
0.993 \\
2.186 \\
1.973 \\
1.929 \\
1.696 \\
1.573 \\
1.430 \\
1.566 \\
1.572 \\
1.743\end{array}$ & $\begin{array}{l}1.996 \\
1.908 \\
1.878 \\
1.989 \\
1.643 \\
1.914 \\
2.186 \\
2.076 \\
1.992 \\
1.908 \\
1.601 \\
1.601 \\
1.601 \\
1.974 \\
3.384 \\
4.104 \\
2.978 \\
2.998 \\
3.534 \\
3.448 \\
3.366 \\
3.366 \\
3.888\end{array}$ & $\begin{array}{l}-1.501 \\
-1.377 \\
-1.383 \\
-1.518 \\
-1.186 \\
-1.341 \\
-1.562 \\
-1.551 \\
-1.364 \\
-1.299 \\
-0.916 \\
-0.941 \\
-1.003 \\
-1.381 \\
-2.456 \\
-2.963 \\
-1.793 \\
-1.580 \\
-1.993 \\
-1.764 \\
-1.818 \\
-1.824 \\
-2.517\end{array}$ & $\begin{array}{l}3.25 \\
3.18 \\
3.19 \\
2.98 \\
2.87 \\
2.48 \\
2.47 \\
2.77 \\
2.43 \\
2.72 \\
2.94 \\
3.33 \\
3.32 \\
3.30 \\
6.75 \\
6.57 \\
5.50 \\
5.45 \\
5.55 \\
5.41 \\
5.91 \\
6.46 \\
6.63\end{array}$ & $\begin{array}{l}1.54 \\
1.46 \\
1.43 \\
1.58 \\
1.21 \\
1.37 \\
1.54 \\
1.56 \\
1.51 \\
1.46 \\
1.69 \\
1.69 \\
1.69 \\
1.36 \\
2.48 \\
2.91 \\
2.11 \\
2.22 \\
2.50 \\
2.48 \\
2.48 \\
2.48 \\
2.90\end{array}$ & $\begin{array}{l}-.93 \\
=.78 \\
=.76 \\
-.70 \\
-.22 \\
+.01 \\
=.15 \\
-.47 \\
-.08 \\
-.32 \\
-.77 \\
-1.16 \\
-1.15 \\
-.80 \\
-1.72 \\
-1.97 \\
-0.10 \\
-0.16 \\
-0.54 \\
-0.38 \\
-0.88 \\
-1.43 \\
-2.02\end{array}$ & $\begin{array}{l}41.04 \\
41.56 \\
40.32 \\
37.92 \\
38.46 \\
32.03 \\
32.21 \\
34.33 \\
32.68 \\
32.86 \\
35.32 \\
41.72 \\
40.56 \\
38.73 \\
78.50 \\
77.11 \\
69.59 \\
63.36 \\
64.44 \\
63.76 \\
70.92 \\
76.43 \\
75.86\end{array}$ & $\begin{array}{l}3.54 \\
3.29 \\
3.87 \\
3.76 \\
3.05 \\
3.10 \\
3.16 \\
3.15 \\
3.38 \\
3.60 \\
2.48 \\
2.48 \\
2.48 \\
4.02 \\
6.75 \\
8.31 \\
6.76 \\
6.60 \\
7.38 \\
6.75 \\
6.82 \\
6.82 \\
8.13\end{array}$ & $\begin{array}{l}-2.10 \\
-2.37 \\
=1.71 \\
+0.80 \\
+0.97 \\
+7.35 \\
+7.11 \\
+5.00 \\
+6.42 \\
+6.02 \\
+4.68 \\
=1.72 \\
-0.56 \\
-0.27 \\
+0.49 \\
+0.32 \\
+9.39 \\
+15.78 \\
+13.92 \\
+15.23 \\
+8.00 \\
+2.49 \\
+1.75\end{array}$ \\
\hline
\end{tabular}

* Testosterone periods. Diet values for testosterone experiment (3-day periods) are as follows: CA, $1.586 \mathrm{Gm}$; P, $3.86 \mathrm{Gm}$.; N, $42.48 \mathrm{Gm}$.

† Exercise periods. Diet for exercise experiment (6-day periods) are as follows: CA, $3.114 \mathrm{Gm} . ; \mathrm{P}, 7.51 \mathrm{Gm}$. ; $\mathrm{N}, 85.74 \mathrm{Gm}$.

were analyzed for nitrogen, phosphorus, and calcium. Urines were analyzed for 17 -ketosteroids in one patient (J. W.). Analytic methods used were as follows: Nitrogen, Kjeldahl (5); phosphorus, Fiske and Subbarow (6); calcium, Fiske and Logan (7); 17-ketosteroids (8); erythrocyte sedimentation rate, Rourke and Ernstene (9).

The designs of the experiments are shown graphically in Figures 1 and 2. All previous medications and applications of heat were omitted. Complete bed rest was instituted one week before the control periods except in the testosterone experiment, during which M. M. was permitted lavatory privileges. The testosterone propionate was administered intramuscularly in oil in doses of $25 \mathrm{mg}$. per day.
The exercises consisting of combined hip and knee extension and trunk flexion were administered to both patients on equipment described by De Lorme and Watkins (1) which allowed exact repetition of the positioning of the patient and measurement of the amount of work done. Exercise loads were based on tests made prior to the control periods which determined the maximum load which could be repeated ten times. Approximately 50 (J. W.) and 75 (M. M.) per cent of this maximum were used as warm-up exercises. The patients were given two periods of exercise each day. M. M. did a daily work load of 21,000 foot pounds at a rate of 1,000 to 1,600 foot pounds per minute. J. W. did a total of 107,300 foot pounds work performing hip and knee extension at a rate of 5,100 foot

TABLE II

J. W.-Nitrogen, phosphorus, and calcium balance data (in grams per period) *

\begin{tabular}{|c|c|c|c|c|c|c|c|c|c|}
\hline Period & $\begin{array}{c}\text { CA } \\
\text { stool }\end{array}$ & $\underset{\text { urine }}{\text { CA }}$ & $\begin{array}{c}\text { CA } \\
\text { balance }\end{array}$ & $\underset{\text { stool }}{\mathbf{P}}$ & $\underset{\text { urine }}{P}$ & $\underset{\text { balance }}{\mathbf{P}}$ & $\underset{\text { stool }}{N}$ & $\underset{\text { urine }}{\mathrm{N}}$ & $\underset{\text { balance }}{\mathbf{N}}$ \\
\hline $\begin{array}{l}1 \\
2 \\
3 \\
4 \\
5 \dagger \\
6 t \\
7 \dagger \\
8 \dagger\end{array}$ & $\begin{array}{l}1.025 \\
1.025 \\
1.310 \\
1.310 \\
1.395 \\
1.395 \\
0.995 \\
0.995\end{array}$ & $\begin{array}{l}0.658 \\
0.811 \\
0816 \\
0.830 \\
0.840 \\
0.789 \\
0.809 \\
0.766\end{array}$ & $\begin{array}{l}-0.636 \\
-0.789 \\
-1.079 \\
-1.093 \\
-1.188 \\
-1.137 \\
-0.757 \\
-0.714\end{array}$ & $\begin{array}{l}0.90 \\
0.90 \\
1.185 \\
1.185 \\
1.25 \\
1.25 \\
0.90 \\
0.90\end{array}$ & $\begin{array}{l}2.15 \\
2.23 \\
2.05 \\
2.04 \\
1.84 \\
2.05 \\
1.94 \\
1.85\end{array}$ & $\begin{array}{r}+0.25 \\
+0.17 \\
+0.06 \\
+0.07 \\
+0.21 \\
+0.00 \\
+0.46 \\
+0.55\end{array}$ & $\begin{array}{l}3.57 \\
3.57 \\
4.50 \\
4.50 \\
4.06 \\
4.06 \\
3.48 \\
3.48\end{array}$ & $\begin{array}{l}38.57 \\
38.79 \\
37.59 \\
35.77 \\
34.97 \\
34.17 \\
33.20 \\
33.64\end{array}$ & $\begin{array}{r}+2.29 \\
+2.07 \\
+2.34 \\
+4.16 \\
+5.40 \\
+6.20 \\
+7.75 \\
+7.31\end{array}$ \\
\hline
\end{tabular}

- Diet values are as follows (3-day period): CA, 1.047 Gm.; P, 3.30 Gm.; N, 44.43 Gm. $\dagger$ Exercise periods. 


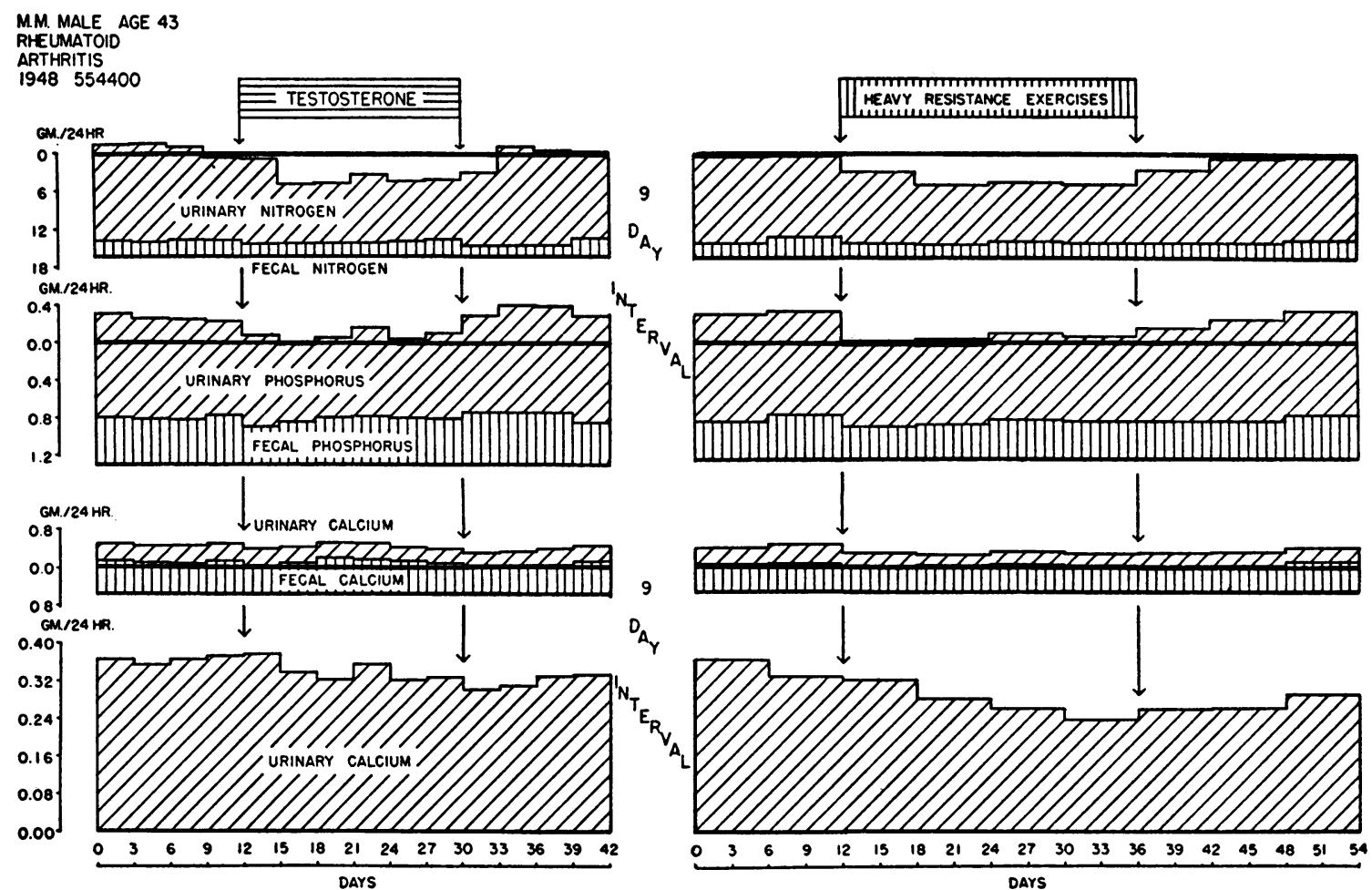

Fig. 1. M. M. Nitrogen, Phosphorus, and Calcium Balances and Urinary Calcium during Testosterone and EXERCISE EXPERIMENTS

pounds per minute. During the period of study his maximum strength increased from 38 to 60 pounds on the left and from 54 to 73 pounds on the right, a gain of 22 and 19 pounds, respectively. The single repetition maximum exercise load increased from 50 to 70 pounds. On the trunk flexion exercise the daily work load was 6,900 foot pounds and totalled 83,200 foot pounds at a rate of 3,200 foot pounds per minute. The strength tests revealed an increase from 30 to 45 pounds during the exercise period. The combined total external work done daily amounted to 15,900 foot pounds.

\section{RESULTS}

\section{Clinical}

Both patients experienced an improved sense of well-being and diminution of fatigue toward the end of the exercise program. Articular symptoms or swelling did not increase in either patient during this period. There were no changes in the manifestations of the arthritis in M. M. during the administration of testosterone. M. M. gained approximately $1.0 \mathrm{Kg}$. in weight while receiving testosterone and $1.2 \mathrm{Kg}$. during the exercise period. J. W. gained approximately $0.4 \mathrm{Kg}$. during the exercise period. Changes in muscle mass could not be accurately estimated in that girth measurements were unsatisfactory. Erythrocyte sedimentation rates did not change significantly in either patient during these studies.

\section{Metabolic}

Results of balance studies are tabulated in Tables I and II and shown graphically in Figures 1 and 2. The following scheme of illustrating balance data is used. Intake is plotted downward from a horizontal baseline marked zero, and stool and urine values are plotted upward from the intake line. Shaded areas above the base-line indicate negative balances and clear areas below the baseline indicate positive balances. The ordinate scales for nitrogen, phosphorus, and calcium are chosen on the basis of ratios for protoplasm and bone so that phosphorus balance should equal the sum of the corresponding areas for nitrogen and calcium balances (4). The following results were observed:

a. Nitrogen metabolism: Nitrogen retention occurred during the exercise periods in both patients. The daily averages for nitrogen retained in excess 


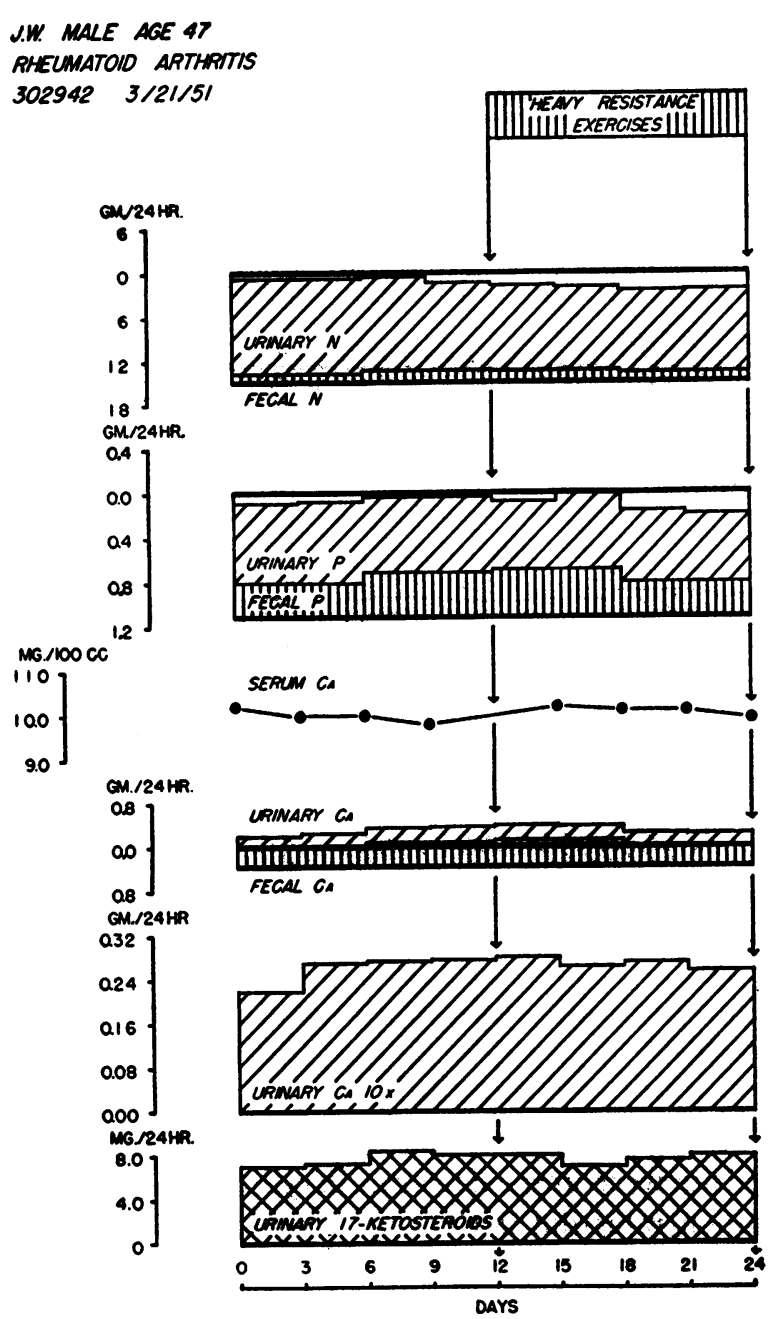

Fig. 2. J. W. Nitrogen, Phosphorus, and Calcium Balances, Serum and Urinary Calcium, and Urinary 17-KETOSTERoIdS DURING EXERCISE EXPERIMENT

of the average during control periods was 2.26 grams for M. M. and 1.30 grams for J. W. Testosterone caused nitrogen retention in M. M. at a rate of 1.38 grams per day.

b. Phosphorus metabolism: Phosphorus was retained by both patients during exercise and also by $M$. M. during the administration of testosterone. The decrease in phosphorus excretion by M. M. during exercise and testosterone periods was associated with decreased calcium and nitrogen excretion. The decreased phosphorus excretion in J. W. during exercise was associated with decreased nitrogen excretion while the calcium excretion remained unchanged. Theoretical phos- phorus balances were derived from the following formula (4):

Theoretical $\mathrm{P}$ balance

$$
=\frac{\mathrm{Ca} \text { Balance }}{2.23}+\frac{\mathrm{N} \text { Balance }}{14.7} \text {. }
$$

Although close correlation existed between theoretical and actual phosphorus balances during the testosterone experiment in M. M., a constant and unexplained discrepancy was noted in both patients during the exercise experiments (Table III). By

TABLE III

Theoretical (2) and actual phosphorus balances

\begin{tabular}{lcc}
\hline \hline & $\begin{array}{c}\text { Theoretical } \\
\text { P balance }\end{array}$ & $\begin{array}{c}\text { Actual } \\
\text { P balance }\end{array}$ \\
\hline M. M. Control & Gm. per day & $\begin{array}{c}\text { Gm. per day } \\
\text { M. Testosterone }\end{array}$ \\
M. M. & -0.26 & -0.24 \\
M. M. Control & -0.07 & -0.08 \\
M. M. Exercise & -0.30 & -0.20 \\
J. W. Control & -0.19 & -0.02 \\
J. W. Exercise & +0.05 & -0.07 \\
\hline
\end{tabular}

correcting for these discrepancies, it was found that M. M. retained nitrogen and phosphorus in a ratio of 11.9 , and $\mathrm{J} . \mathrm{W}$. in a ratio of 13.6 during the exercise periods. ${ }^{5}$

c. Calcium metabolism: Both exercise and testosterone decreased urinary calcium in patient M. M. Exercise did not alter urinary calcium in patient J. W. Retention of calcium in M. M. was greater during exercise than during testosterone therapy.

d. 17-Ketosteroid excretion: The excretion of 17 -ketosteroids did not change during exercise in patient J. W.

\section{DISCUSSION}

Although there were no definite objective changes in the rheumatoid arthritis of these two patients during the period of vigorous daily exercises, each noted an improved sense of wellbeing and increased endurance. These changes

- Theoretical phosphorus balances based on nitrogen were obtained by subtracting phosphorus gained or lost with calcium (Calcium balance $\div 2.23$ ) (4) from actual phosphorus balances. The phosphorus retained with nitrogen during treatment periods was derived by subtracting the control values of theoretical phosphorus based on nitrogen from treatment values. 
were attributed to the phenomenon of "conditioning" or "training," a physiologic response which can not be defined from these data. The absence of an increase in 17-ketosteroids in patient J. W., suggests that these subjective phenomena were not due to adrenocortical stimulation.

Nitrogen-phosphorus ratios, derived from these experimental data, were less than the ratio of 14.7 calculated for muscle protein from balance studies (4) and the ratio of 15.3 ( 0.065 gram of $P$ per 1 gram of $\mathrm{N}$ ) calculated from analysis of human, collagen-free muscle (10). It is apparent, however, that both nitrogen and phosphorus were retained and approximately in proportion to their content in muscle, and that under the conditions of these experiments, resistance exercises had a protein anabolic effect similar to testosterone (11).

Chemical studies on muscle tissue from patients with rheumatoid arthritis by Bien, Ziff, and $\mathrm{Bu}$ nim (12), have shown decreases in both myosin and collagen content. Observations reported here, suggest that a mechanism for regeneration of muscle protein is available in this disease when the proper stimulus is present. The absence of increases in nitrogen, phosphorus, and calcium excretion in both patients and the failure of urinary 17 -ketosteroids to rise in $\mathrm{J}$. W. indicate that the exercises did not initiate the usual adrenocortical responses to stress, i.e., the alarm reaction of Selye (13). The metabolic responses to physical exertion observed in these experiments were similar to those observed by Deitrick, Whedon, and Shorr in normal subjects during restoration of physical activity after prolonged immobilization (3). It should be noted that heavy resistance exercises could have harmful effects in patients with rheumatoid arthritis which were not observed in these experiments.

\section{SUMMARY AND CONCLUSIONS}

Resistance exercises resulted in a protein anabolic effect in two patients with active rheumatoid arthritis and a decreased excretion of calcium in one. These same effects were observed in one subject during the administration of testosterone. However, exercise did not alter the excretion of 17 -ketosteroids in the one patient on whom such determinations were made.

\section{ACKNOWLEDGMENT}

The authors are indebted to Dr. Fuller Albright for determinations of 17 -ketosteroids and to Dr. Herbert Park and Misses Janet Appleton, Katherine Brine, and Elizabeth Manning for technical assistance.

\section{REFERENCES}

1. De Lorme, T. L., and Watkins, A. L., Progressive Resistance Exercise. Technic and Medical Application. New York, Appleton Century-Crofts, 1951.

2. Cathcart, E. P., The influence of muscle work on protein metabolism. Physiol. Rev., 1925, 5, 225.

3. Deitrick, J. E., Whedon, G. D., and Shorr, E., Effects of immobilization upon various metabolic and physiologic functions of normal men. Am. J. Med., 1948, 4, 3.

4. Reifenstein, E. C., Jr., Albright, F., and Wells, S. L., The accumulation, interpretation, and presentation of data pertaining to metabolic balances, notably those of calcium, phosphorus, and nitrogen. J. Clin. Endocrinol., 1945, 5, 367, Erratum, Idem.: Ibid., 1946, 6, 232.

5. Folin, O., and Wright, L. E., A simplified macroKjeldahl method for urine. J. Biol. Chem., 1919, 38, 461.

6. Fiske, C. H., and Subbarow, Y., The colorimetric determination of phosphorus. J. Biol. Chem., 1925, 66, 375 .

7. Fiske, C. H., and Logan, M. A., The determination of calcium by alkalimetric titration. II. The precipitation of calcium in the presence of magnesium, phosphate, and sulfate, with applications to the analysis of urine. J. Biol. Chem., 1931, 93, 211.

8. Fraser, R. W., Forbes, A. P., Albright, F., Sulkowitch, H., and Reifenstein, E. C., Jr., Colorimetric assay of 17-ketosteroids in urine. A survey of the use of this test in endocrine investigation, diagnosis, and therapy. J. Clin. Endocrinol., 1941, 1, 234.

9. Rourke, M. D., and Ernstene, A. C., A method for correcting the erythrocyte sedimentation rate for variations in the cell volume percentage of blood. J. Clin. Invest., 1930, 8, 545.

10. Baldwin, D., Robinson, P. K., Zierler, K. L., Lilienthal, J. L., Jr., Interrelations of magnesuim, potassium, phosphorus, and creatine in skeletal muscle of man. J. Clin. Invest., 1952, 31, 850.

11. Kenyon, A. T., Knowlton, K., Sandiford, I., Koch, F. C., and Lotwin, G., A comparative study of the metabolic effects of testosterone propionate in nor$\mathrm{mal} \mathrm{men}$ and women and in eunuchoidism. Endocrinology, 1940, 26, 26.

12. Bien, E. J., Ziff, M., and Bunim, J. J., Chemical constituents of skeletal muscle from normal subjects and patients with rheumatic and non-rheumatic diseases. Proc. Soc. Exper. Biol. \& Med., 1951, 76, 646.

13. Selye, H., The physiology and pathology of exposure to stress. A treatise based on the concepts of the general-adaptation-syndrome and the diseases of adaptation. Montreal, Acta, Inc., 1950. 